\title{
Lumen
}

Selected Proceedings from the Canadian Society for Eighteenth-Century Studies

\section{Time and Exile: The Case of Mme la Marquise de Lage de Volude}

\section{Rosena Davison}

Volume 18, 1999

Representations of Time in the XVIIIth Century

Le temps et ses représentations au dix-huitième siècle

URI : https://id.erudit.org/iderudit/1012367ar

DOI : https://doi.org/10.7202/1012367ar

Aller au sommaire du numéro

Éditeur(s)

Canadian Society for Eighteenth-Century Studies / Société canadienne d'étude du dix-huitième siècle

ISSN

1209-3696 (imprimé)

1927-8284 (numérique)

Découvrir la revue

Citer cet article

Davison, R. (1999). Time and Exile: The Case of Mme la Marquise de Lage de Volude. Lumen, 18, 69-82. https://doi.org/10.7202/1012367ar

Copyright (c) Canadian Society for Eighteenth-Century Studies / Sociéte canadienne d'étude du dix-huitième siècle, 1999
Ce document est protégé par la loi sur le droit d'auteur. L'utilisation des services d'Érudit (y compris la reproduction) est assujettie à sa politique d'utilisation que vous pouvez consulter en ligne.

https://apropos.erudit.org/fr/usagers/politique-dutilisation/ 


\section{Time and Exile: The Case of Mme la Marquise de Lage de Volude}

The French Revolution caused a radical change in people's perception of time. The acceleration of time experienced in the upheavals would affect all who were living in France, throwing them into a dizzying confusion where none of the previous traditions were respected, not even the calendar. For some, time went by sickeningly fast as they faced danger, terror and death, the urgent need to escape exacerbating the slippery peculiarity of time running out. For others, time dragged its feet as they waited for an end to the nightmare which had put in power people who had little respect for time-honoured traditions and rights. For those waiting in exile, time weighed heavily. When would the King return? When would the monarchy be restored? When could they return to their beloved France? Reading the memoirs written at that time, we come to realize that, after centuries of permanence, time ceased to have the same significance for the transitional society at the end of the eighteenth century in France. In those pages, we read how turmoil and impermanence had replaced stability, insecurity had supplanted centuries of certainty.

That final decade of the eighteenth century brought changes to French society which would have repercussions not only in France but throughout western Europe; some of those escaping from the Revolution would travel as far as Africa, Asia, the United States and Canada. The douceur de vivre of the Ancien Régime had vanished with alarming rapidity. As a result, approximately 150,000 people decided to emigrate, leaving no part of French society untouched. Most, but not all, were privilégiés, but there were also around 33,000 priests, and about $20 \%$ of the total emigration were members of the Third Estate. ${ }^{1}$ Only $15 \%$ of the emigrating nobility was female; a much higher percentage of working class and peasant women emigrated. In this article I would like to look at how the compression of time during exile affected one woman in particular, the Marquise de Lage de Volude.

Her life had been typical of a person of her rank. Educated at a convent for daughters of the nobility, she was married at the age of eighteen to 
the Comte de Lage de Volude, presented to the King and Queen, and chosen by the Princesse de Lamballe as her companion. Immensely proud of her family's aristocratic origins and fiercely loyalist, she was emotionally ill-equipped to deal with the excesses of the Terror, especially the massacre of Mme de Lamballe and two of her uncles who were bishops, and finally with the death of Louis XVI and Marie-Antoinette. For Mme de Lage, the idea that the Ancien Régime would never return was unacceptable: she remained faithful to the principles of her parents and to the memories of her childhood. That her life and society could change with such speed was inconceivable: she was oblivious to the first signs of the undercurrents of revolutionary change.

At the beginning of the Revolution, many of her contemporaries were also unable to comprehend the gravity of the situation, and we are struck by the incredulity which characterized the reactions of some to the storming of the Bastille. The Marquise de La Tour du Pin, for example, wrote in her memoirs entitled Journal d'une femme de cinquante ans: '[n]otre sécurité était si profonde que le 14 juillet à midi, ou même à une heure plus avancée de la journée, nous ne nous doutions, ni ma tante ni moi, qu'il y eût le moindre tumulte à Paris. ${ }^{2}$ Refusal of the obvious was another common attitude. At the end of her Mémoires, la Baronne d'Oberkirch wrote:

[1]es événements de cette année, ceux que l'on prévoit dans l'avenir m'arrachent la plume des mains. Le 14 juillet, jour de la prise de la Bastille, a vu tomber l'ancienne monarchie. La nouvelle que l'on veut fonder n'a point de racines et ne prendra jamais en France. ${ }^{3}$

It was only later that the truth began to sink in, as the Marquise de La Tour du Pin admits:

Cependant la nuit du 4 août, qui détruisit les droits féodaux sur la motion du vicomte de Noailles, aurait dû prouver aux plus incrédules que l'Assemblée nationale n'en restait pas à ce commencement de spoliation. Mon beau-père $y$ fut ruiné, et nous ne nous sommes jamais relevés du coup porté à notre fortune dans cette séance de nuit, qui fut une véritable orgie d'iniquités.

She explains the differing attitudes of the emigrants towards what was happening to them:

Tout est de mode en France; celle de l'émigration commença alors. On se mit à lever de l'argent sur ses terres pour emporter une grosse somme. Ceux, en grand nombre, qui avaient des créanciers, envisagèrent ce moyen de leur échapper. Les plus jeunes y voyaient un motif de voyage tout trouvé, ou bien un prétexte d'aller 
rejoindre leurs amis et leur société. Personne ne se doutait encore des conséquences que cette résolution pouvait avoir. ${ }^{4}$

The Ancien Régime's disintegration slowly became evident. The golden age of stability and privilege was superseded by the Revolution's momentum, which would intimidate many of Mme de Lage's friends into abandoning their homes and previous existence.

The consequences of emigration became tangible in the form of revolutionary laws which were imposed with implacable rigour against the émigrés. On November 9, 1791 the death sentence was decreed as punishment for emigrating, property was confiscated, and a year later the émigrés were faced with death if they returned to France. By 1793, they were also to be punished for not returning to France. Women and children were not spared in the law of August 15, 1792, even children as young as ten. By the end of 1793, laws were passed affecting even the parents of émigrés, thus breaking family ties, even declaring marriages dissolved by emigration (October 15, 1794). It was further decreed that rewards should be offered to informers to accelerate the number of people arrested, and finally the sale of the émigrés' property was authorized on July $25,1792 .^{5}$

In his Reflections on the French Revolution, Edmund Burke wrote with disbelief of the confiscation of property of nobility:

[p]ossession is nothing; law and usage are nothing [...]. I see the princes of the blood, who, by the oldest usages of that kingdom, held large landed estates [...] deprived of their possessions, and in lieu of their stable independent property, reduced to the hope of some precarious, charitable pension. ${ }^{6}$

Although not connected to property, very specific reasons prompted Mme de Lage de Volude to leave France. Faithful to the principles and traditions which she had inherited from her family and from her position as dame pour accompagner the Princesse de Lamballe, who was lady-inwaiting to Marie-Antoinette, she felt it her duty to ensure the safety of the Princess, and left Paris in 1789 in the first wave of emigrants, on the heels of the Comte d'Artois. No particular courage or heroism was required to emigrate at that time. What makes Mme de Lage's case interesting is that she decided to return to France on more than one occasion to visit her dying mother, in spite of the danger and the fact that she had compromised herself by her association with other emigrants and by her outspoken views on the 'usurpers.'

There were two fundamentally different types of emigrants. First there were the frivolous ones who thought only of their own unachievable hopes and dreams and lived in complete ignorance of the state of 
mind of the French. Secondly there were those who remained faithful to their ideals and showed courage and dignity in the face of their hardship. Some, especially women, even those used to luxury, accepted their plight in exile without complaint, as they passed from wealth to extreme poverty, often working with their hands to support their families. The lucky ones found themselves intellectual jobs such as secretaries or tutors in riding and fencing for men, and drawing, languages, grammar and deportment for women. There were also manual jobs for men such as clock making and wood work, and for women, embroidery and le commerce de la vaisselle. But time was taking its toll: the image of the good old days receded, as hope and resources faded. As Margaret Darrow states,

As funds dwindled and hopes of an early restoration waned, women gave up appearances and worked to support themselves and their families. The stories of former court beauties, struggling to make ends meet, havebeen told and retold - Mme de Rochechouart depleting her fortune in the counter-Revolutionary cause and reduced to decorating hats and boxes; Mme de Saisseval embroidering dresses; the Countess de Neuilly keeping a dress shop. Some, like Mme de Damas and Mme de la Tour du Pin, were dependent upon foreign relatives. Others, like Mme de Saulx-Tavannes, lived upon what little could be sent by relatives still in France, or, like Adèle d'Osmond, sold themselves into humiliating marriages. ${ }^{7}$

Mme de Lage's father was unable or unwilling to comprehend the reality of emigration. She wrote: 'M. d'Amblimont [her father] ne comprenait pas plus notre position sous la Terreur, que si je lui avais parlé en chinois. ${ }^{8}$ In vain did she explain to him that as an émigrée she was an outlaw, and therefore the smallest request on her part to the authorities would expose her and send her to the guillotine. From his safe position in England he persisted in asking why she had not prevented his estate from being sold, why she had let his papers be burned, etc. His response to her explanations was: 'Mais que faisiez-vous donc? C'était bien la peine d'être là pour ne rien sauver!' ${ }^{\prime}$ These were bitter words for a woman who had risked her life to return to France.

Where did most of the emigrants seek refuge? According to Donald Greer,

Switzerland from the first was a terre d'élection for the émigrés. Perhaps 5,000 of them gathered in the canton of Fribourg [...] . The Rhineland was full of them: more than 20,000 crowded into Coblenz and Mannheim. ${ }^{10}$ 
But conditions were far from ideal. In a letter from Brunswick dated November 5, 1792 to Mme de Charrière, Benjamin Constant wrote,

Les chemins sont infestés de malheureux émigrés qu'actuellement tous les pays repoussent et qui n'ont pas la permission, dans la plupart de vos principautés, de séjourner plus de vingt-quatre heures au même endroit. ${ }^{11}$

Mme de Lage had no choice of destination in her first emigration on July 17,1789 ; although she was three months pregnant, she had to flee from Versailles en route to Switzerland, with the Princesse de Lamballe and two other ladies in waiting, Mme de Poulpry and Louise d'Esparbès, Vicomtesse de Polastron, the mistress of the Comte d'Artois. Declaring: '[j]e donnerais mon bras et la moitié de ma fortune pour nous sauver d'une jacquerie', ${ }^{12}$ Mme de Lage was to measure the force of the enemy sooner than she thought:

Nous pensâmes périr à Vesoul, nous rencontrâmes des paysans armés de torches allumées, de fusils et de faux qui venaient de brûler le château de M. de Mesmay. Ils nous firent sortir de voiture et coupèrent quelques traits de cheveux. Ils pensèrent égorger devant nous le cocher $[\ldots]$. Heureusement une partie se déclara pour nous; ils se prirent de querelle [...]. Plusieurs balles avaient percé un panneau de la voiture, le siège et le chapeau du cocher. J'étais grosse et tout à fait écrasée de cette fatigue et de la frayeur. ${ }^{13}$

This type of event was to characterize her life as an émigrée from now on. The time she spent in Switzerland was brief but she returned to Paris only in March 1791 to join Mme de Lamballe.

Her return was undertaken in the belief that it would be on a permanent basis. But she quickly had to readjust to the realities of revolutionary France. Her second departure coincided with the nuit de Varennes when the royal family attempted to leave France on June 20,1791; since the Princesse de Lamballe was asked to accompany them, she took along Mme de Lage. The departure was so precipitous and clandestine that they could only take with them their diamonds, two chemises and their mouchoirs. Six of them were pressed into a flimsy carriage as they began their unusual itinerary; avoiding Amiens, they reached Abbeville, then Boulogne:

Il y avait là un petit bâtiment avec dix hommes d'équipage; on venait de mettre l'embargo, et le capitaine voulut retourner à l'instant. M. de Lage lui montra ses pistolets, saisit le gouvernail et lui enjoignait de continuer sa marche. ${ }^{14}$ 
They made him continue to Dover, where they learned of the arrest of the King. They continued their journey to Ostend, Brussels, Liège, arriving in Aix-la-Chapelle on July 11. The Princesse de Lamballe gave Mme de Lage leave to visit Mme de Polastron in Coblentz; at that time, the Comte d'Artois was enjoying the hospitality of the Elector of Coblentz who provided a base for the royalist army until its defeat in Valmy in 1793.

In the seven-month period between June 1791 and February 1792, three thousand French people took up residence in Coblentz; rents became exorbitant, servants were scarce, wood and coal were worth their weight in gold. The cost of living was so high that Mme de Lage was obliged to sell her diamond chain for twelve thousand livres. Since their absence from Paris was expected to be of short duration, more like an extended vacation, many émigrés lived extravagantly. In fact they attempted to replicate their life at Versailles; as they looked back to the good old times, they wished to create a miniature renaissance of the familiar Ancien Régime. They spent their time gambling, dancing and taking tea, or taking the waters and baths at Aix, all of which required an immense wardrobe. Mme de Lage describes one of the toilettes she ordered for the celebrations in Coblentz:

Mme Bertin [Marie-Antoinette's dressmaker] était auprès de nous, et nous vendait chèrement ses chiffons et ses talents. Voici comment j'étais habillée: j'avais dans les cheveux une guirlande de primevères surmontée de grandes plumes blanches, une robe de taffetas couleur de rose, garnie également en primevères, en blonde et en gaze d'argent, une jupe de gaze d'argent garnie en primevères. On nous présenta au roi de Prusse [...] . Quatre jours de suite avaient employé quatre robes que j'avais fait faire. ${ }^{15}$

The Princesse de Lamballe left Aix on October 15 to join the Queen in Paris but asked Mme de Lage not to accompany her 'malgré ses supplications.' So Mme de Lage remained behind in Coblentz, the main military emigrant centre, and was soon caught up in the social whirl with the Comte de Provence, the Comte d'Artois, who was attempting to organize the émigré army, and the Prince de Condé. This is when she became actively involved in the political scene and acted as an intermediary for the princes. She preferred the Comte d'Artois as a leader; as he criss-crossed Europe to rouse the courts against the Revolution, she fully supported his efforts, and her letters at this time show considerable political astuteness. For example, in December 1791 she wrote,

Si l'on considère les choses intrinsèquement, il n'est pas douteux que le comte d'Artois aurait plus d'autorité pour obtenir l'obéissance et la discipline, qui sont 
beaucoup à la guerre; plus de moyens pour se procurer des ressources en argent et en munitions, plus de prestige pour en imposer aux généraux étrangers, et même aux souverains; plus de force enfin pour soutenir le dévouement de tant de braves, dont plusieurs sont même chevaliers de Saint-Louis. Le nom de Condé est considérable, principalement pour le militaire, mais celui de frère du Roi est tout autre chose et ferait un autre effet, surtout porté par un prince aimable, brave et populaire. $^{16}$

But meanwhile her mother's health was deteriorating rapidly. In spite of the danger involved, Mme de Lage did not hesitate to return to France, where she came face to face with the relentless acceleration of events in revolutionary France. Time was suddenly compressed into a few lifethreatening events, as we see from her account of her nightmarish journey which resembles a cloak and dagger novel. From Coblentz she travelled to Aix-la-Chapelle, then Givet, and Dinant. The crossing of the Meuse 'eut lieu une nuit très obscure au moment d'une forte pluie au milieu des coups de tonnerre et sous la direction d'un batelier ivre. ${ }^{17} \mathrm{At}$ Bellevue the maitre de poste refused them horses; they took refuge in a run-down tavern full of bonnets rouges whose remarks displayed a distinctly sanguinary disposition. On more than one occasion Mme de Lage had to resort to her unsuspected talents as an actress: this time she pretended to be ill, was taken pity on by a servant girl who convinced her father to drive her, hidden in his cart, to the next stop where the maittre de poste quickly prepared horses. Near Soissons the carriage was besieged by patriots and soldiers determined to 'se faire des cravates avec les entrailles des princes.' Holding a copy of Gil Blas 'pour faire bonne contenance', Madame de Lage tried to hide her terror. An innkeeper's wife who had recognized her origins, took pity on her, gave her her own room and put her under the protection of a traveller wearing a bonnet rouge but royalist at heart.

She made it to Paris by July 28, 1792 at a very dangerous moment, just as the Marseillais were leaving, and a few days before August 10, 1792, when the mob invaded the Tuileries, and Louis XVI and his family were imprisoned in the Temple. It was also one month before the September massacres; Mme de Lamballe went to the guillotine on September 3. To leave Paris, Mme de Lage had to obtain a passport under a false name; having done that, she found that the postillions claimed there were no more horses available. However, she did eventually reach Bordeaux where she found her mother in better health, and was reunited with her children who had been left in her mother's care. How slowly time must have passed for her children, awaiting the arrival of their mother, and how quickly it passed for Mme de Lage, faced with these life threatening situations. 
Bordeaux had been suffering from a severe famine, 'véritable fléau qui désolait Bordeaux depuis longtemps.' In her Souvenirs d'émigration, Mme de Lage wrote,

On ne pouvait avoir de pain que quelques morceaux donnés par les autorités; on allait à la queue à sa section recevoir par personne, chaque jour, ou six pommes de terre, ou douze noix, ou une poignée de riz qu'on payait fort cher. Les soldats vendaient leur pain: ma mère achetait six francs par jour celui d'un des gardiens qu'on avait laissé chez elle. ${ }^{18}$

Mme de Lage was warned that as an émigrée who had returned to France, she had to go into hiding immediately: the gendarmes of Pons had received an order to arrest and imprison her. As what she termed a 'raffinement de cruauté', her mother could no longer keep the children with her unless she signed a document declaring that her daughter was an emigrant, which was tantamount to condemning her to the guillotine. So Mme de Lage had to disguise herself and go to live in a shack in the country which she described as being more like a tomb than solitude, spending her time writing, drawing and reading. She stayed there for five weeks and, unable to bear it any longer, made the mistake of returning to her mother's house. As of September 27, 1793 her name appeared on the official list of émigrés, her furniture was seized and the revolutionary police was searching for her. Bordeaux was in the throes of the full horror of the Terror: heads on pikes were paraded along the streets and the most venerated priests were being sent to the guillotine. Early one morning, not long after her return from the country, her mother's house was searched by four gendarmes while Mme de Lage was still in bed. Her maid Rosalie outwitted them and took her to the apothecary Cazalet who in turn accompanied her to Mme Coutanceau, the mid-wife. In order to stay there she had to be pregnant, the appearance of which was rapidly arranged through the use of towels. While in hiding, she had many misgivings about endangering others. In her Souvenirs she wrote:

[s]i j'avais sçu avant tous les chagrins que j'éprouverais dans cette maison, ce que c'est que d'avoir tous les jours l'effroy de compromettre la vie de ceux qui vous rendent service $[\ldots]$ certainement je me serais laissé arrêter. ${ }^{19}$

Meanwhile as a precaution, her mother had burned all her papers, including her letters, except those of the last 18 months. As Mme de Lage once again prepared to flee, she learned of the death of the Queen on October 16, 1793. Time had completely erased the world she had known, the world of her childhood; in very few years it had been transformed 
from a peaceful, predictable place to one which witnessed the worst excesses of the Terror. She felt that her only option was to flee to another world, the New World, where she hoped to be able to start a new life.

Using rather dubious contacts through a certain Mme de Fontenay, mistress of Tallien, the député de la Convention, Mme de Lage, under the pseudonym of Mme Renard, was eventually able to obtain at great cost another false passport as an American whose husband had already left France. At last she was able to leave Bordeaux on the Swedish ship Fulgant bound for New York, where she had already sent her eldest daughter Nathalie. She was dismayed to discover several jacobins enragés amongst the passengers. On March 12, the boat encountered an English corsair; and was taken over by an English privateer who stole the cargo. On the same day a French corsair appeared and a battle ensued between the two. Favourable winds enabled the French vessel to escape but these same winds were unfavourable for going to America. The captain wished to go to Monserrat but a storm blew up, breaking the mast in two and forcing the ship to turn back and put in at the nearest port in Spain, which was La Coruña. After difficult negotiations over whether she was to be allowed to go ashore, Mme de Lage eventually made her way to Madrid where she found quite a large emigrant community from southern France, including members of her own family. Her intentions to settle there with her family were frustrated by the slowness of Spanish administration, but she did meet the Comtesse de Montijo, who became a close friend, and for whom she wrote the Souvenirs d'émigration.

From Madrid she left for Lisbon, where she set sail for London. Arriving in March 1795 she was reunited with her father, her husband and her brother-in-law, and her old friend Mme de Polastron, the mistress of the Comte d'Artois who would arrive himself on August 7. Life would be arduous from now on: since she had sold her jewellery, she now had to find work such as embroidery, and painting and selling fans for the American market. She lived in a modest house which she shared with Mme de Polastron and Mme de Poulpry and where the Comte $\mathrm{d}^{\prime}$ Artois would come to spend his evenings. She had to be careful of spies, only too common in the world of the émigrés, and would open her house only to those she was sure of, such as Las Casas, the Spanish ambassador. This is how Chateaubriand, who was in London at the same time, described the émigré community:

Mes compagnons à Londres avaient tous des occupations; les uns s'étaient mis dans le commerce du charbon, les autres faisaient des chapeaux de paille, d'autres enseignaient le français. Ils étaient tous bien gais. Le défaut de notre nation, la légèreté, s'était dans ce moment changé en vertu. On riait au nez de la 
fortune; cette voleuse était toute penaude d'emporter ce qu'on ne lui redemandait pas. ${ }^{20}$

At the beginning of 1797 we find Mme de Lage in Hamburg, hoping to get permission to cross France en route to Spain in order to see her mother again. This being denied to her, she went to Switzerland and Italy, but crossing the St. Gothard pass proved to be very hazardous and she had serious doubts about surviving it. She reached Milan, then Turin, where she crossed paths with Mme Bonaparte, and then Genoa. She then made a ten-day journey by sea to Barcelona during which the vessel lost all its sails and one mast. Mme de Lage was very ill. In Madrid she was joined briefly by her husband before he left for Puerto Rico where the Spanish government had given him a territorial concession. Having brought her daughter Calixte to Madrid, she had to think seriously about her education: the royal convent Las Salesas was recommended by Mme de Montijo, so she reluctantly agreed to the separation. Mme de Lage lived in a modest house, and spent her days accompanying the Countess on her visits to charitable institutions, and keeping up her correspondence with her French friends. She was soon to learn of the death of her husband, followed not long after by that of Calixte.

In 1800 Mme de Lage decided to return to France again to see her mother. Ten years had elapsed since her second emigration. During that time, all vestiges of the old world had been stripped away. Nothing remained that she was familiar with: she had become a stranger, an outcast. In Paris she was able to measure the full extent of the upheaval which France had just experienced, and was shocked and saddened by what she saw. This is how she expressed her indignation about the new French society which had evolved during the years of her emigration:

J'étouffe au sujet de tout ce que je vois, et j'ai pris le parti de ne point aller dans le monde parce qu'avec mon caractère, ma franchise et mon irritation devant certaines manières, cela me serait impossible. Oh! Ma chère, rien ne peut donner l'idée de l'unique occupation que l'on a prise de conserver ou de se procurer de l'argent, du manque d'éducation et de l'absence de tout respect. Les enfants de notre société ne sont guère mieux que les autres. Ils justifient leur conduite, leur avidité pour l'argent, leur passion pour le jeu, par des raisonnements qui me font plus de mal que leur conduite. J'ai le coeur navré! Je sentais bien l'impossibilité d'y vivre avec mes sentiments et loin de mes amis, mais depuis que j'ai touché la réalité, ma résolution est bien plus irrévocable: ils me tueraient à force de chagrins. ${ }^{21}$

In fact, death did seem quite close for a while: for a two-month period in 1802 in Barcelona (where the Spanish court was in residence) she was 
hovering between life and death after an attack of pneumonia. Her slow and painful convalescence was the result of the exhaustion from her endless journeys, her isolation, her anxiety, and her lack of money. She was helped at this time by her devoted friend Mme de Montijo, who invited her to stay with her. It was there that she dictated her Souvenirs covering the period of her journey from Coblentz to Paris, from Paris to Bordeaux, and her stay under the Terror in Bordeaux, until her arrival in Madrid.

The situation of Mme de Lage eventually improved: the King of Spain granted her a pension of five thousand livres representing a sum owed to her father for his service to the Spanish navy, which on his death became payable in part to his daughter; and the maison de Savoie also paid her a pension of eight thousand livres in memory of the Princesse de Lamballe. After the marriage of her daughter Nathalie to an American, which she at first vigorously opposed and to which she later acquiesced, Mme de Lage continued to travel in Europe and finally spent five years in Saintonge from 1807 to 1812, where she was able to observe the sad situation of émigrés like herself:

Évincés de leurs domaines par des intrus, dépossédés de leurs biens par d'anciens laquais, ceux qui rentrent n'ont comme ressource que de s'établir dans les villes voisines où, avec les débris de leur fortune, ils tâchent de faire figure honorable. Angoulême, Périgueux, Poitiers, Saintes sont remplis d'émigrés ruinés, qui y font revivre l'éducation, les manières et le bon goût de l'ancien temps [...]. Ces survivants d'un autre âge s'abstiennent fièrement de toute compromission, et évitent de se mêler à la population des villes où ils demeurent. ${ }^{22}$

She noted with undisguised satisfaction the growing discontent in the country over requisitions and the endless wars. 'Aristocratique jusqu'à la moelle des os', ${ }^{23}$ she adamantly refused to lend her house to Napoleon and his wife when they visited Saintes in 1808; meanwhile she showed great generosity to charities for the Spanish prisoners who were arriving in large numbers. The year 1812 was one of the cruellest for Mme de Lage. After her mother's death in May she was besieged by creditors and was obliged to sell everything: the beloved home to which she constantly returned during her exile no longer belonged to her.

But what of the amnesties granted to some émigrés? Ironically,

the legal repatriation of the émigrés was essentially Bonaparte's work [...]. His partial [...] amnesty of October 20, 1800 readmitted the peasants, the artisans, the deported clergy, most of the women of all classes, and all children under sixteen - fifty-two thousand people. ${ }^{24}$ 
But Mme de Lage's intractable attitude would not permit her to accept such a compromise until 1807, the year of her return to France. Her first attempt to return to Paris was doomed:

Ses allées et venues avaient fini par attirer sur elle l'attention de la police impériale [...] et le 3 juin 1813 elle était dénoncée à Savary 'comme coupable de manoeuvrer contre la sûreté de l'Etat. ${ }^{25}$

This would be the last time that she had to suffer such persecution. In 1814 she was back in Paris again, where she watched with great emotion the solemn entry into the city of Louis XVIII who had left England on April 20. Apart from her absence during the hundred days of Napoleon's return, a trip to Germany and to Prague in 1835 and 1836 to visit Charles $X$, Mme de Lage would spend the rest of her life mostly in Paris.

Throughout her life she never wavered in her support for the royal family. From the moment when the Bourbon monarchy first fell in 1792 until its final disappearance in 1830, Mme de Lage's loyalist passion inspired her to work ceaselessly for her masters, courageously facing danger, exile, and sacrifices. She would live until 1842, but her long life was a mixed blessing: she had to witness the fall of the monarchy, the July Revolution and the death of Charles X, in fact the end of all she believed in. In a letter referring to the death of her mother in 1812, we can feel that time is already weighing heavily on her and it is still too painful to recall the past:

Le temps n'affoiblit point l'impression d'une telle perte; le changement de lieu n'en diminue point les angoisses [...]. L'isolement où cette perte me jette ne peut être senti que par moi; on ne peut pas en avoir une idée, ne sachant pas combien elle étoit toujours mon but et mon premier objet [...]. Tout ce que j'ai aimé dans ma jeunesse, tous ceux avec qui ou au milieu desquels j'ai commencé à vivre n'existent plus. Le souvenir est un supplice pour moi; je ne puis me rappeler ni ma jeunesse, ni mes heureuses années, ni mes liens les plus doux et les plus sacrés sans être entourée de morts. ${ }^{26}$

The sentiments she is expressing at the loss of her mother perfectly echo her feelings about the end of the monarchy. She could accept neither. In spite of the hardships of her exile, her faith in the monarchy never wavered as time passed; she remained until the end rooted in the life and beliefs of the Ancien Régime.

We have followed the turbulent life of an émigrée who like so many others was thrust into an unfamiliar and dangerous world. Within a few years, as we have seen, she experienced a total upheaval in her life. The turning 
point of modern European history had destroyed her world. She had no time to adjust to this new régime before she had to leave, and the Terror confirmed that she had made the right decision, however hasty. According to Greer, 1158 nobles were executed and 16431 fled the country either to fight the Revolution of to escape from it. ${ }^{27}$ In spite of her many attempts in several countries, Mme de Lage was unable to settle into a new life. Her constant travel confirms this. Unlike many other émigrés, who created communities very similar to their previous life in France, Mme de Lage could not attach herself for any length of time to any community. With the restoration of the monarchy, her world was re-established after a twenty-five year disruption: it was as if the intervening years had not existed, and time's restorative balm had healed the bad memories.

ROSENA DAVISON

Simon Fraser University

\section{Notes}

1 Donald Greer, The Incidence of the Emigration during the French Revolution (Gloucester, Mass.: Peter Smith, 1966) 95.

2 Mémoires de la marquise de La Tour du Pin. Journal d'une ferme de cinquante ans (Mercure de France, 1989) 101.

3 Baronne d'Oberkirch, Mémoires sur la cour de Louis XVI et la société française avant 1789, présenté par Suzanne Burkard (Paris: Mercure de France, 1970) 500.

4 La Tour du Pin 107.

5 Colin Jones, The Longman Companion to the French Revolution (London: Longman, 1988) 194-197. See also Vicomte de Broc, Dix ans de la vie d'une femme pendant l'émigration: Adélaïde de Kerjean, marquise de Falaiseau (Paris: Plon, 1893) 37.

6 Edmund Burke, 'Reflections on the French Revolution' Burke and Paine on the Revolution and Rights of Man, ed. Robert Dishman (New York: Scribner, 1971) 101.

7 Margaret H. Darrow, 'French Noblewomen and the New Domesticity, 1750-1850', Feminist Studies 5, 1 (Spring 1979) 49.

8 Quoted by Alfred Mézières, 'La Marquise de Lage de Volude', Pages d'automne (Paris, 1911) 153.

$9 \mathrm{Ibid}$. In her book Isabelle de Charrière, une aristocrate révolutionnaire. Écrits 1788-1794 (Paris: Des Femmes, 1988), Isabelle Vissière writes: 'Il y a certes la foule des irréductibles qui n'ont rien compris, rien appris, et se figent dans le culte d'un passé révolu' (249).

10 Greer 93. 
11 Quoted by Vissière 245.

12 Quoted by Arthur Chuquet, 'La Marquise de Lage', Episodes et portraits 1, (1909) 213.

13 Souvenirs d'émigration de Madame la Marquise de Lage de Volude (Evreux: Hérissey, 1869) 59.

14 Ibid. 71.

15 Letter quoted by Pierre de Vaissière, Lettres $d^{\prime}$ 'aristrocrates': la Révolution racontée par des correspondances privées 1789-1794 (Paris: Perrin, 1907) 173.

16 Letter to Mine de Polastron quoted by the comtesse H. de Reinach-Foussemagne, Une fidèle. La Marquise de Lage de Volude, 1764-1862 (Paris: Perrin, 1908) 85.

17 Souvenirs 87.

18 Ibid. 189.

19 Ibid. 145.

20 Chateaubriand, Mémoires d'Outre-tombe, vol. 11 (Paris, 1848) 86.

21 Letter dated November 4, 1800. Quoted by comtesse H. de Reinach-Foussemagne, Une fidèle, 200.

22 Ibid. 264.

23 Chuquet 213.

24 Greer 105

25 Une fidèle 299.

26 Souvenirs clx-clxi.

27 Greer, 127. 